\title{
The Effect of Using a Language Games-Based Electronic Program on Acquiring Oral Expression Skills among People with Learning Difficulties in English Language during Covid-19 Pandemic
}

\author{
Mohamad Ahmad Saleem Khasawneh \\ Special Education Department, King Khalid University, Saudi Arabia \\ mkhasawneh@kku.edu.sa
}

\begin{abstract}
The purpose of this study was to identify the effect of using a language games-based electronic program on developing the oral expressions of people with learning difficulties in the English language during the emerging Covid-19 pandemic. The study used the experimental approach and implemented the program on a sample of 84 students, who were distributed to an experimental group (42) and a control group (42). The instruments of the study consisted of the training program and a test for the evaluation of oral expressive performance. The study found the existence of significant differences between the experimental and control groups in the acquisition of oral expression after receiving the training program in favor of the experimental group.
\end{abstract}

Keywords: Language Games, Learning Difficulties, English Language, Oral Expressions, COVID-19.

\section{INTRODUCTION}

The new COVID-19 virus spread from China to the rest of the world resulting in the death of more than 300 thousand people. The number of confirmed cases is now more than 100 million cases. COVID-19 affects people in different ways, some cases result in severe illness and the need for hospitalization while the symptoms could be mild for some others. However, vulnerable groups, such as elderly people, persons with disabilities, and people with chronic diseases are the most exposed to the danger of the virus. The impacts of COVID-19 touched all sectors, including the education sector. The educational institutions shifted to online learning because of the lockdowns and curfews that governments decided to impose to reduce the spread of the virus. Online education, within these circumstances, faced several challenges.

MANAZHIM : Jurnal Manajemen dan Ilmu Pendidikan

Volume 3, Nomor 2, Agustus 2021; 136-150

https://ejournal.stitpn.ac.id/index.php/manazhim 
Oral expressions are one of the requirements for proper linguistic communication, as they occupied a prominent position in the English language courses for the basic stage classes in the Kingdom of Saudi Arabia. They reflect the use of the grammar of the English language. They consist of syntactic concepts compatible with the mental growth of students in the early stages. These patterns consist of the parts of speech (noun, verb, etc.) and the structures these parts can compose, such as the nominative or verbal sentences and various methods, interrogation, exclamation...etc.

Teaching oral expressions at this stage is of special importance as it prepares students to learn grammatical rules in the future, trains them to use sound linguistic structures and patterns in oral expression, helps them formulate useful sentences and phrases, and organizes ideas (Al-Helah, 2018). Language games are very important in the educational field according to several studies that have shown their effectiveness. However, no studies have been conducted that have used language games in developing language patterns and oral expression skills, according to the researcher's knowledge. Therefore, the researcher investigated their use and experimented with the effect of using a program based on language games on developing oral expression skills for those with learning difficulties in the English language in the Aseer region.

\section{PROBLEM STATEMENT}

There is a large gap in communication between teachers with students with learning difficulties and their families during the Corona pandemic. The current world health situation imposed the application of distance online learning at all levels. This application of electronic tools revealed a clear weakness in the effectiveness of applications for electronic educational platforms, in addition to the general weakness in the infrastructure, whether in the availability of tools, or the Internet, and the teachers' ability and competence in applying online learning process. Several obstacles also face resource rooms' teachers represented in not being exposed to such a crisis and its repercussions before, and the difficulty of teaching students with learning difficulties in such circumstances. This category of students suffers from problems with attention, concentration, memory, and perception, which also add to 
the problem. Therefore, this study aimed at developing an electronic educational program to mitigate the effects of the emerging coronavirus crisis on students and help teachers in providing online learning.

\section{Research Objectives}

This study attempted achieving the following objectives:

- Identifying the effectiveness of a language games-based electronic program on the acquisition of oral expressions among people with learning difficulties in the English language during the COVID-19 pandemic.

\section{Research Questions}

The present study seeks to answer the following research questions:

- What is the effectiveness of a language games-based electronic program on the acquisition of oral expressions among people with learning difficulties in the English language during the COVID-19 pandemic?

\section{Significance of the Study}

The significance of this study comes through finding effective ways to teach oral expression skills in an interactive, responsive, and manner of understanding of linguistic patterns. This study follows the recent trends that confirm the effectiveness of using games in teaching, because of their great impact on stimulating the learner's motivation and excitement (Sabarini \& Ghazawi, 2014).

\section{Delimitations of the Study}

There are several limitations to the generalization of the results of this study, which can be summarized as follows: 
1. The sample of the study was limited to students with English language learning difficulties, registered with the Education Department in the Aseer region.

2. This study was limited to the following instruments:

a. The educational program was prepared by the researcher.

b. Pre and post-achievement test.

c. The test of oral expression performance.

\section{Definition of Operational Terms}

\section{Language games:}

In this study, language games are the games the researcher chooses or modified, and which students participate in (experimental sample), and which are applied in a specific time and place and according to specific rules to help students with learning difficulties acquire linguistic patterns and oral expressions in the English language.

\section{Oral expressions:}

Oral expression is the ability to deliver needs, wants, ideas and thoughts in a meaningful manner of using the appropriate syntactic, pragmatic, semantic, and phonological language structures (Samak, 2015)

\section{The educational program:}

The program is a written document that includes the objectives, knowledge, activities, and skills or behaviors, which the training will strive to achieve among the trainees (Hamdan, 2016).

As for the proposed educational program, it is defined in this study as a set of knowledge and activities that are prepared for students using the method of language games to create a change in the oral linguistic behavior and the linguistic patterns of the students. 


\section{LITERATURE REVIEW}

COVID-19 had negative impacts on persons with disabilities in the psychological, social, and economic aspects of this category of people (United Nations, March 2020). Although many protective measures were done to reduce the impact on persons with disabilities, these efforts face different challenges in implementation. The special health of persons with disability increase their vulnerability to being infected and affected by any kind of virus, and sometimes the cases become worse if the person is infected with COVID-19 (Singh et al. 2020).

Playing is an integral part of human life because of its great importance for young and old ages alike. Through playing, the child learns and develops the growth of mental and cognitive activity. Playing has also become an educational tool that contributes to the child's interaction with the environment, and a tool for communication between children regardless of the linguistic and cultural differences between them. It also helps them to individualize learning, highlights the internal motivations for learning, and is an opportunity for social interaction.

One of the most prominent projects that emerged in the revolution in the use of technologies, and focused on the use of language games in teaching English as a foreign language, was the project Schrand did to analyze English language curricula used in Britain at the end of the eighties of the last century. Schrand focused on linguistic models and concluded in his study that textbooks lack language games that attract students' attention, and push them to effective learning in the basic education stage in particular. The study included suggestions for training on specific skills through the use of language games, such as comprehension, developing the ability to question, suggesting the implementation of games, and training skills, either through cooperative learning within groups, or through bilateral work (Nimrat, 2005).

\section{Previous Studies}

Research needs to investigate deeper into the impact of COVID-19 on students in general, and students with disabilities in particular. Because coronavirus is still new, there is a lack of information about the health conditions surrounding the 
infections. Few studies tackled the issue of the impact of coronavirus on students with disabilities and the measures taken to combat its effect on different categories.

Mumtaz et al (2021) examined and highlighted the effectiveness and challenges caused by the change from traditional to online education during the COVID-19 pandemic in developing countries such as Pakistan. To achieve this, the study reviewed 32 full-text papers published in the last ten years from 2010 to 2020. These studies were collected using websites and search engines such as Medline database, Web of Science, Google Scholar, and Google using keywords like " Covid-19, elearning, mental health, social impact, academics and combination of words". This study concluded that the curfews resulted in a major change in the education world, such as the suspension of learning and shifting to online education.

Zhang et al (2020) identified the academic and psychological effects of the COVID19 pandemic on students with disabilities in the United States of America, with a study sample that included 147 students with and with disabilities. The results of the study showed that students with disabilities were more interested in lessons transmitted via the Internet than were their regular peers. Additionally, students with disabilities reported more difficulties accessing the Internet compared to their regular peers. Also, the results of the study indicated that psychological pressures related to anxiety and fear of studying were higher among students with disabilities than among their peers without disabilities.

Skalski et al. (2020) evaluated the relationship between the anxiety and trauma caused by a coronavirus and the resiliency of individuals and the social support. The study used the Coronavirus Anxiety Scale (CAS) as developed in Poland. The sample of the study consisted on 515 individuals aged 18-78. The results revealed that social support and resiliency if they have higher rates help in decreasing the level of anxiety caused by a coronavirus. The results also indicated that the participants needed to engage in the intervention measures about raising resiliency and receiving social support to help to boost mental health during the COVID-19 pandemic.

Windak et al (2020) focused on the challenges academia faced, specifically in education, research, and quality assurance. This article concluded that the recent COVID-19 pandemic has brought different challenges to education, research, and 
quality assurance in health. The study stressed the need that health and medical research should change the styles and tools of research to face the challenges of COVID-19. The pandemic can also be an alert to change the primary care, especially in providing online consultations and supporting people to learn about self-care. The ultimate goal of the health sector should be to provide a higher quality of care, reducing health care costs, and reducing the workload on the physicians.

Al-Weissi (2019) investigated the effect of using computerized electronic games on the eighth-grade students' acquisition of the components of language and motivation. The study relied on the semi-experimental method. The sample of this study consisted of 58 eighth grade students from Suhaib Al-Roumi School in Anbar, and they were divided into two groups, an experimental group of 28 students who were taught by using electronic games, and a control group consisting of 30 students who were taught through the traditional method. This study lasted for 8 weeks, where students from both groups were subjected to a test to determine their level before the start of the study and then were subjected to a post-test. The results showed that the level of the two groups before the start of this study was almost equal, and there were no statistical differences between the performance of the two groups in the post-test concerning the language components: grammar, vocabulary, and culture. The results showed differences in the views of the experimental group towards the use of electronic games for education in a positive way.

Yukselturk et al (2018) identified the effectiveness of using game-based education with Kinect technology in foreign language learning courses on the self-efficacy and behaviour towards the English language of students. This study was conducted at a government university in central Turkey, and the study sample consisted of (62) male and female students from the first year of university who are studying the English language as a compulsory subject. The study was based on the semi-experimental approach, whereby students were subjected to a quasi-experimental test before and after starting this study. The study tools consisted of two questionnaires to measure the degree of self-efficacy and behaviours towards the English language. This study showed a positive increase in some factors for the behaviours and self-efficacy of students in the experimental group compared to the control group. The study 
showed the importance of introducing educational activities based on games using Kinect technology in teaching foreign language courses.

\section{RESEARCH METHODOLOGY}

\section{Population and Sample}

The study population consisted of students with learning difficulties in the English language and their number was (3310) students, distributed over (54) schools and (85) classrooms. The sample of the study consisted of (84) students enrolled in the academic year 2020/2021.

\section{Research Instrument}

\section{First: the educational program:}

The researcher prepared the educational program on language games, to develop oral expression skills. The program consisted of a set of language games, exercises, and educational activities that were designed to provide students with an opportunity to practice these activities, processes, and procedures in the experimental group. These exercises and activities were subjected to the formative evaluation and final evaluation processes, which is the same pre-test prepared by the researcher for the study, and it has sufficient indications of validity and reliability.

\section{The validity of the educational program:}

To verify the validity of the proposed educational program, the researcher presented this program in its initial form to a panel of qualified judges in the field of education. In light of the observations made by the judges, the necessary modifications were made and the program was designed in its final form.

\section{Second: Achievement test (pre-post-tests):}


The researcher prepared an achievement test designed to measure students' knowledge and use of language patterns for this study. The test was derived from the objectives of the educational program to measure the achievement of the study sample before studying the content of the prescribed subject and after studying it. The test in its final form consisted of twenty items, all of the multiple-choice type.

The validity of the test:

To verify the validity of the test, the researcher adopted the evaluations of the judges and their opinions to reveal the extent of agreement in their assessments, which is the approved method for determining the validity of the test.

Reliability of the test:

Reliability is an important feature of any test. It indicates the stability of the subjects' results if the test is repeated on the same group (Odeh, 2016). One of the methods used by the researcher in calculating the test reliability factor is the Test-re-Test method, which requires that the test be performed on a specific group of students, extract its results, and then repeat the same test on the same group after a specified period has elapsed.

To verify the stability of the instrument, the researcher administered the test to a sample from outside the study sample, consisting of (39) students, which was applied again after two weeks to the same sample. The Pearson correlation coefficient between the results of the two applications was calculated, which was (0.83). This correlation is a suitable reliability coefficient for the present study (Odeh, 2016).

\section{Third: the Oral Expressions test:}

To identify the effect of the language games method and the prevailing method in teaching oral expressions, the researcher prepared a questionnaire that included ten titles for different topics, appropriate to the age and mental level of the students. These various topics are of interest to students and activate their enthusiasm. 
The researcher presented these topics to a committee of judges. They were asked to choose four headings, which they thought would be more appropriate for students of the fourth grade. The judges' selections were based on themes (cleanliness is civilized, the beautiful springtime, adherence to traffic etiquette, and the blessed olive tree).

The researcher then prepared a list of the oral expression skills needed for people with learning difficulties in the English language and presented it to several specialists, who expressed their observations, and the researcher took these notes and made adjustments in light of their recommendations.

\section{Data Analysis}

The researcher used the appropriate statistical methods to answer the questions of this study:

- Calculating the mean scores and standard deviations for the performance of the study sample from the experimental and control groups on the tests of language patterns and oral expression skills, to make comparisons between them.

- The researcher used the t-test to determine the differences between the mean scores on the achievement test and the oral expression test and to detect differences at the statistical significance $(\alpha=0,05)$.

\section{RESULTS AND DISCUSSION:}

To answer the question of the study, the frequency distribution and percentage of the study sample scores were calculated on the post-test for language patterns, and for the members of the experimental and control groups, as shown in Table (1). 
Table (1): The frequency distribution and percentage of students' grades on the posttest of language expressions according to the teaching method

\begin{tabular}{|c|c|c|c|c|c|c|}
\hline \multirow{3}{*}{$\begin{array}{l}\text { Scores } \\
\text { categories }\end{array}$} & \multicolumn{4}{|c|}{ Teaching method } & \multirow{2}{*}{\multicolumn{2}{|c|}{ Total }} \\
\hline & \multicolumn{2}{|l|}{ Traditional } & \multicolumn{2}{|c|}{ Language games } & & \\
\hline & Frequency & percentage & Frequency & percentage & $\begin{array}{l}\text { Total } \\
\text { Frequency }\end{array}$ & percentage \\
\hline $19-15$ & 5 & $\% 50$ & 0 & $\% 0$ & 5 & $\% 25$ \\
\hline $24-20$ & 5 & $\% 50$ & 9 & $\% 90$ & 14 & $\% 70$ \\
\hline $30-25$ & 0 & $\% 0$ & 1 & $\% 10$ & 1 & $\% 5$ \\
\hline Total & 10 & $\% 100$ & 10 & $\% 100$ & 20 & $\% 100$ \\
\hline
\end{tabular}

Table (1) shows that no students got marks less than (15), while the number of students who got more than 15 marks was (20) students. The maximum score for the test was (30).

The number of students who obtained more than (19) grades in the experimental group that was taught by language games was (10) students, and they constituted $(100 \%)$, and in the control group that was taught using the traditional method was (5) students, and they constitute $50 \%$.

The mean scores and standard deviations of the students' scores were calculated on the post-test for language patterns according to the two study groups, where the results were as shown in Table (2).

Table (2): the mean scores and standard deviations of students' scores on the posttest in oral expressions according to the teaching method

\begin{tabular}{||l|l|l|l||}
\hline Teaching method & No. & Mean score* & $\begin{array}{l}\text { Standard } \\
\text { deviation }\end{array}$ \\
\hline Traditional & 10 & 20.100 & 1.931 \\
\hline Language games & 10 & 23.667 & 1.432 \\
\hline
\end{tabular}

*Maximum score (30) 
Table (2) shows that the mean score of the marks of the experimental group students was (23.667), and for the marks of the students of the control group was (20.100) on the total test. The maximum mark for the test is (30) marks. The standard deviation of the scores of the experimental group students was (1.432), while the standard deviation of the scores of the students of the control group was (1.931).

Table (3) shows the results of the T-test analysis of the scores of the students of the experimental and control groups on the oral expressions test.

Table (3): The results of the "T" test analysis for the differences between the mean scores of the two study groups on the post-linguistic patterns test

\begin{tabular}{||l|c|c|c|c|c||}
\hline \hline $\begin{array}{l}\text { Teaching } \\
\text { method }\end{array}$ & Mean score & $\begin{array}{c}\text { Standard } \\
\text { deviation }\end{array}$ & $\begin{array}{c}\text { Freedom } \\
\text { value }\end{array}$ & T value & Sig.* \\
\cline { 1 - 4 } Traditional & 20.100 & 1.931 & 18 & 4.692 & ${ }^{*} 0.000$ \\
\cline { 1 - 3 } & 23.667 & 1.432 & & & \\
\hline
\end{tabular}

*Statistically significant at $(\alpha=0.05)$.

Table (3) shows the existence of fundamental differences between the mean scores of students of the experimental group and the scores of students of the control group on the test of oral expressions. There were significant differences between students' scores on the post-test of language patterns, and these differences were in favor of the experimental group that was taught by the method of language games. This indicates that there is an effect of the educational program based on language games in developing the oral expressions of people with learning difficulties in the English language.

The result of the " $\mathrm{T}$ " test revealed the realization that there was an effect of the training program based on language games in improving students' ability to acquire oral expressions. The results showed the superiority of the experimental group 
students who were taught oral expressions using the language games strategy over the control group students who were not subject to the educational program.

The researcher believes that this result is due to the following reasons:

The activities, exercises, and games used in the training program trained the students of the experimental group to employ the language, to speak it freely with their colleagues, and to develop verbal interaction. This was positively reflected in their verbal expression. The program also worked on organizing individual and group situations, as these encouraged students to speak without fear, hesitation, or confusion.

There is another factor that can be taken into consideration that led to the high performance of students in oral expression skills. Language games are one of the activities that aim to educate students, as they make them more effective and participate in the educational situation. Language games put students in situations that excitingly resemble daily life, which is interesting for students' learning. This indicates that language games are effective in acquiring students' oral expression skills.

The program also created a sense of confidence, self-reliance, and responsibility for the students during the classroom session. The student became aware that the oral expression class is important and includes discussion, dialogue, and the freedom to present opinions and ideas in front of their colleagues. This made students more interested in what they say because their colleagues would listen to and they would be exposed to direct criticism. This exercise pushed students to choose the appropriate combinations and vocabulary for the topic to succeed in expression and avoid embarrassment. Therefore, this style created a positive interaction among the students.

In the oral expression lesson, the researcher used the method of dialogue, discussion, and questioning, which stimulated students' thinking, and this, in turn, increased their ability to express orally. 


\section{Recommendations:}

In light of the results of this study, the researcher recommends the following:

1. Designing language games to teach oral expressions of people with learning difficulties in the English language.

2. Preparing some language games for selected topics in the first four grades, attached with the teacher's guide.

3. Conducting studies similar to the current study in grades other than those in which the study was conducted.

4. Conducting studies similar to the current study on language skills other than (oral expression).

5. Developing a methodology for teaching oral expression skills in the teacher's guide, and the different academic stages.

Acknowledgments

The authors extend their appreciation to the Deanship of Scientific Research at King Khalid University for funding this work through Small Research Groups under grant number (RGP.1 /40/42).

\section{REFERENCES}

Al-Beblawi, V. (2015). Children and Toys. Alam Al-Fiker Journal, ed 10, 3, pp. 111 152.

Al-Dulaimi, T. and Al-Waeli, S. (2013). Practical methods in teaching Arabic. Amman: Dar El Shorouk.

Al-Helah, Muhammad (2018). Educational games and production techniques. Amman. Dar Al Fikr Publishers and Distributors.

Al-Nimrat, M. M. (2005). The effect of using language games in the English language curriculum "Petra" on vocabulary achievement of tenth-grade students in the Qasbah Amman schools. Unpublished MA thesis, University of Jordan Amman: Jordan.

Al-Weissi, A. A. (2019). The effect of using computerized electronic games on the eighth-grade students' acquisition of language and motivation components in Iraq for learners of English as a foreign language. Unpublished MA Thesis, Al al-Bayt University, College of Education. 
Al-Rabihat, G. A. (2017). The effectiveness of language games strategy in developing speaking skills in the Arabic language subject for fourth-grade students. Journal of Educational and Psychological Sciences, National Research Center, Gaza.

Belqis, A. and Mari, T. (2011). Facilitator in the psychology of play. Amman. Dar Al Fikr publishers and distributors.

Hamdan, M. Z. (2016). Design and implementation of training programs. Amman. Dar Al Fikr Publishers and Distributors.

Mumtaz, N., Saqulain, G., \& Mumtaz, N. (2021). Online academics in Pakistan: COVID-19 and beyond. Pakistan Journal of Medical Sciences, 37(1), 283.

Samak, M. S. (2015). The art of teaching language education. Amman. Dar Al Fikr Publishers and Distributors.

Odeh, Ahmed (2016). Measurement and evaluation in the teaching process. Amman. Dar Al Fikr Publishers and Distributors.

Sabarini, M. S. and Ghazzawi, M. T. (2015). Educational games and their applications in science. The Arabian Gulf Message, 21, pp. 121-145.

Singh, A. K., Gupta, R., \& Misra, A. (2020). Comorbidities in COVID-19: Outcomes in hypertensive cohort and controversies with renin-angiotensin system blockers. Diabetes \& Metabolic Syndrome: Clinical Research \& Reviews. https://doi.org/10.1016/j.dsx.2020.03.016

Skalski, S., Uram, P., Dobrakowski, P., \& Kwiatkowska, A. (2020). The Link Between Ego- resiliency, Social Support, SARS-CoV-2 Anxiety, and Trauma Effects. Polish Adaptation of the Coronavirus Anxiety Scale. DOI: 10.31234/osf.io/56hjc.

Tummers, J., Catal, C., Tobi, H., Tekinerdogan, B., \& Leusink, G. (2020). Coronaviruses and people with intellectual disability: An exploratory data analysis. Journal of Intellectual Disability Research. https://doi.org/10.1111/jir.12730

United Nations. (March 2020). Shared Responsibility, Global Solidarity: Responding to the Socio-Economic Impacts of Covid-19, March 2020. https://unsdg.un.org/resources/shared-responsibility-global-solidarityresponding-socio-economic-impacts-covid-19

Windak, A., Frese, T., Hummers, E., Klemenc Ketis, Z., Tsukagoshi, S., Vilaseca, J., ... \& Ungan, M. (2020). Academic general practice/family medicine in times of COVID-19-Perspective of WONCA Europe. European Journal of General Practice, 26(1), 182-188.

Yukselturk, E., Altıok, S., \& Başer, Z. (2018). Using Game-Based Learning with Kinect Technology in Foreign Language Education Course. Journal of Educational Technology \& Society, 21(3), 159-173.

Zhang, H., Nurius, P., Sefidgar, Y., Morris, M., Balasubramanian, S., Brown, J., ... \& Mankoff, J. (2020). How Does COVID-19 impact Students with Disabilities/Health Concerns?. arXiv preprint arXiv:2005.05438. 